\title{
Inhibition of NADPH Oxidase-Derived Reactive Oxygen Species Decreases Expression of Inflammatory Cytokines in A549 Cells
}

\author{
Joanna Wieczfinska, ${ }^{1}$ Przemyslaw Sitarek, ${ }^{2}$ Ewa Skala, ${ }^{3}$ Tomasz Kowalczyk, ${ }^{2}$ and \\ Rafal Pawliczak ${ }^{1,4}$
}

Abstract-Various experimental models strongly support the hypothesis that airway inflammation can be caused by oxidative stress. Inflammatory airway diseases like asthma and COPD are characterized by higher levels of ROS and inflammatory cytokines. One of the sources of ROS is NADPH oxidase. Therefore, the aim of the study was to investigate influence of NADPH oxidase inhibition on the expression of IL-6, IL-8, TNF, TSLP, CD59, and PPAR- $\gamma$ in vitro. A549 cells were incubated with apocynin in three concentrations $(0.5 \mathrm{mg} / \mathrm{ml}, 1 \mathrm{mg} / \mathrm{ml}$, and $3 \mathrm{mg} / \mathrm{ml})$. Cells were trypsinized and RNA isolated after $1 \mathrm{~h}, 2 \mathrm{~h}$, and $4 \mathrm{~h}$ of apocynin incubation at each concentration. Afterwards, reverse transcription was performed to evaluate mRNA expression using real-time PCR. The time-response and dose-response study showed that apocynin significantly influenced the relative expression of chosen genes (IL-6,IL-8,TNF, PPAR- $\gamma, T S L P$, and CD59). Apocynin decreased the mRNA expression of TNF- $\alpha$ at all concentrations used, and of IL-6 at concentrations of 1 and $3 \mathrm{mg} / \mathrm{ml}(p<0.05)$. TSLP mRNA expression was also reduced by apocynin after $1 \mathrm{~h}$ and $2 \mathrm{~h}$, and CD59 mRNA after $1 \mathrm{~h}$, but only at the highest concentration. The expression of PPAR- $\gamma$ was reduced after apocynin in the highest concentrations only $(p<0.05)$. The results might suggest that proinflammatory agents' expression levels are strongly connected to the presence of oxidative stress generated by NADPH oxidase and this might be at least partially eliminated by anti-oxidative action. Apocynin, as an effective inhibitor of

\footnotetext{
${ }^{1}$ Department of Immunopathology, Medical University of Lodz, 7/9 Zeligowskiego, Bldg 2, Rm 122, 90-752 Lodz, Poland

${ }^{2}$ Department of Biology and Pharmaceutical Botany, Medical University of Lodz, Lodz, Poland

${ }^{3}$ Department of Genetics and Plant Molecular Biology and Biotechnology, The University of Lodz, Lodz, Poland

${ }^{4}$ To whom correspondence should be addressed at Department of Immunopathology, Medical University of Lodz, 7/9 Zeligowskiego, Bldg 2, Rm 122, 90-752 Lodz, Poland. E-mail: rafal.pawliczak@csk.umed.lodz.pl
} 
NADPH oxidase, seems to be useful in potential anti-oxidative and anti-inflammatory therapy.

KEY WORDS: inflammatory cytokines; oxidative stress; apocynin.

\section{INTRODUCTION}

Oxidative stress is a harmful process leading to the development of many respiratory inflammatory diseases, like asthma and chronic obstructive pulmonary disease (COPD) though airway damage. The superoxide is a precursor of other ROS and RNS. Inhibition of its generation seems to be an important therapeutic target. This can be achieved by the use of apocynin, a molecule that inhibits the activation of NADPH oxidase by blocking one of its subunits [1-5].

It has been shown that lung cells release inflammatory mediators and cytokines/chemokines, such as IL-6, IL-8, and TNF- $\alpha$ in response to oxidative stress [6, 7]. Levels of IL-6 have been shown to be elevated in a number of inflammatory diseases such as asthma and COPD [8-10]. Liu et al. report that NAC attenuated the release of particulate matter-induced IL-6 in mouse plasma, suggesting that ROS play a role of in IL-6 regulation [11].

It has been suggested that IL- 6 is involved in the repair process responding to oxidative stress and depletion of reduced glutathione [12-14]. IL-6 has been demonstrated to have a protective effect against oxidative stress and mitochondrial dysfunction, as indicated by the increased toxicity of ROS in IL-6-deficient mice [14-16], and IL-6 has been found to be specifically induced as a response to disturbed redox status [14]. The increased concentration of serum IL-6 usually correlates with an increase in TNF- $\alpha$ concentration, both of which have a similar origin in the inflammatory processes [14]. TNF- $\alpha$ itself induces the expression of multiple airway epithelial cell genes, including those coding for such cytokines as IL-6 and IL-8 [17].

It is well documented that IL- 8 production takes place in alveolar epithelial cells after oxidative stress $[18,19]$, and its inhibition might be connected with inflammatory clinical symptoms.

In COPD, it is possible that oxidative stress from cigarette smoke contributes towards elevated TSLP expression in BAL fluid $[20,21]$. Nakamura et al. showed that CSE induced TSLP expression in the mouse lung in a manner dependent on oxidative stress and TNF-A- $\alpha$ receptor I level [22]. Similar findings from mouse models have been observed in human asthmatic subjects, where higher concentrations of TSLP have been detected in the lungs, correlating with Th2-attracting chemokines and disease severity [20,21, 23]. This phenomenon is connected with oxidative stress and antioxidants might potentially regulate it. Oxidative stress is also associated with a decrease in PPAR- $\gamma$ expression. Blanquicett et al. demonstrated that oxidative stress, potentially through activation of inhibitory redox-regulated transcription factors, attenuates PPAR- $\gamma$ expression and activity in vascular endothelial cells through suppression of PPAR- $\gamma$ transcription [24]. Recent studies have suggested that oxidative stress modulates PPAR- $\gamma$; for example, $\mathrm{H}_{2} \mathrm{O}_{2}$-induced oxidative stress was found to significantly reduce PPAR- $\gamma$ activity in renal tubular epithelial cells [25] and osteoblasts [24, 25].

CD59 is a membrane anchored complement regulatory protein that inhibits membrane attack complex (MAC) formation, thereby preventing complement-mediated cell lysis [26-28]. Li et al. detected high expression of CD59 in the tissues of patients with lung cancer. CD59 expression in non-small cell lung cancer tissues is much higher than in the surrounding tissue, and suggests that CD59 might be a biomarker for lung cancer progression [29]. Many of the known inflammatory target proteins, such as matrix metalloproteinase-9 (MMP-9), intercellular adhesion molecule-1 (ICAM-1), vascular cell adhesion molecule-1 (VCAM-1), cyclooxygenase-2 (COX-2), and cytosolic phospholipase A2 (cPLA2), are associated with NADPH oxidase activation and ROS overproduction in response to proinflammatory mediators $[6,30-35]$. Thus, oxidative stress regulates both key inflammatory signal transduction pathways and target proteins involved in airway and lung inflammation [6].

Because oxidative stress, also generated by NADPH oxidase, contributes to inflammatory pathology, the aim of the study was to evaluate the influence of apocynin (NADPH oxidase inhibitor) on the expression of selected genes involved in the inflammation and antioxidant reactions in A549 cells (IL-6, IL-8, TNF- $\alpha$, PPAR- $\gamma$, TSLP, and CD59). 


\section{MATERIALS AND METHODS}

\section{Cell Culture}

A549 cells, a human adenocarcinoma cell line, were obtained from ECACC (European Collection of Cell Cultures, Heath Protection Agency, Salisbury, UK) and were grown in Ham's F-12K medium (Sigma-Aldrich, St. Louis, MO) with $10 \%$ fetal bovine serum and $2 \mathrm{mM}$ of $1-$ glutamine (Sigma-Aldrich, St. Louis, MO). All experiments were performed after six to nine passages $(n=6)$, when the cell sheets were 80 to $90 \%$ confluent.

\section{Experimental Procedure}

A549 cells were incubated with apocynin at three concentrations $(0.5 \mathrm{mg} / \mathrm{ml}, 1 \mathrm{mg} / \mathrm{ml}$, and $3 \mathrm{mg} / \mathrm{ml})$. These concentrations were selected experimentally as the most effective. The experiments were also performed in the absence of the stimulus (control).

The cells were trypsinized and RNA was isolated after $1 \mathrm{~h}, 2 \mathrm{~h}$, and $4 \mathrm{~h}$ of apocynin incubation with each concentration. Following this, reverse transcription was performed to assess mRNA expression using real-time PCR. A time-response and dose-response study showed that apocynin significantly influenced the relative expression of the selected genes $(I L-6, I L-8, T N F-A, P P A R-\gamma, T S L P$, and $C D 59$ ).

\section{RNA Extraction and cDNA Synthesis}

Total RNA was isolated from the stimulated cells using RNeasy Cell Mini Kit with QIAshredder (Qiagen). RNA was DNase treated, purified, eluted in $30 \mu \mathrm{l}$ of RNase-free water, and stored at $-80{ }^{\circ} \mathrm{C}$ for further analysis. Total RNA $(1 \mu \mathrm{g})$ was reverse transcribed using High Capacity cDNA kit (Applied Biosystems, Foster City, CA, USA). All procedures were carried out according to the protocols given by the producer.

\section{Analysis of Gene Expression}

Real-time PCR was conducted in order to indicate the changes in expression of $I L-6, I L-8, T N F-A, P P A R-$ $\gamma, T S L P$, and CD59. cDNA was subjected to qPCR using the assays designed for the selected genes (Life Technologies, Carlsbad, CA); each sample was measured in duplicate using a TaqMan analyzer 7900 (Life Technologies, Carlsbad, CA). Using the $2^{-\Delta \Delta C t}$ method, data was presented as gene expression normalized to $\beta$-actin as an endogenous reference gene and relative to a control. The fold change of mRNA expression in each patient was calculated by comparing RQ $\left(2^{-\Delta \Delta \mathrm{Ct}}\right)$.

\section{Statistical Analyses}

The results were analyzed using Statistica software (v. 10.0; StatSoft, Tulsa, OK). The distribution of data and the equality of variances were checked by the Shapiro-Wilk test and Levene's test, respectively. Significant changes were determined by ANOVA, with the appropriate post hoc tests as multiple comparison procedure. Values of $p<0.05$ were considered statistically significant.

\section{RESULTS}

\section{Apocynin Decreased mRNA Expression of Proinflammatory Cytokines}

Lung epithelial cells in the respiratory tract are the first barrier in contact inhaled oxidants, and A549 human lung epithelial cells have been wildly used as in vitro models to assess airway inflammation, asthma, and respiratory sensitization, and, in case-control studies, for in vivo validation [36-40].

The expression of the proinflammatory cytokines analyzed in the study appeared to be decreased by apocynin. Real-time PCR analysis revealed a significant decrease in IL-6 mRNA expression $2 \mathrm{~h}$ and $4 \mathrm{~h}$ for $3 \mathrm{mg} / \mathrm{ml}$ apocynin $(p<0.05)$, but only after $2 \mathrm{~h}$ for $1 \mathrm{mg} / \mathrm{ml}$ apocynin $(p<0.05$, Fig. 1). Interestingly, apocynin significantly decreased TNF-A mRNA expression in all doses and at all time points $(p<0.05$, Fig. 2). However, while no significant changes in IL-8 expression were caused by apocynin, decreases in IL-8 expression were observed for all administered concentrations $(p>0.05$, Fig. 3).

\section{The Effect of Apocynin on CD59 and TSLP mRNA Expression}

CD-59 mRNA expression was significantly influenced by $3 \mathrm{mg} / \mathrm{ml}$ apocynin after $1 \mathrm{~h}$ of application $(p<0.05)$. A similar, but insignificant, relationship was also observed after $2 \mathrm{~h}$, but no such relationship was found after $4 \mathrm{~h}(p>0.05$, Fig. 4$)$.

Similarly, a significant decrease of TSLP mRNA expression was observed for all doses of apocynin after $1 \mathrm{~h}$ of application. Only the highest 


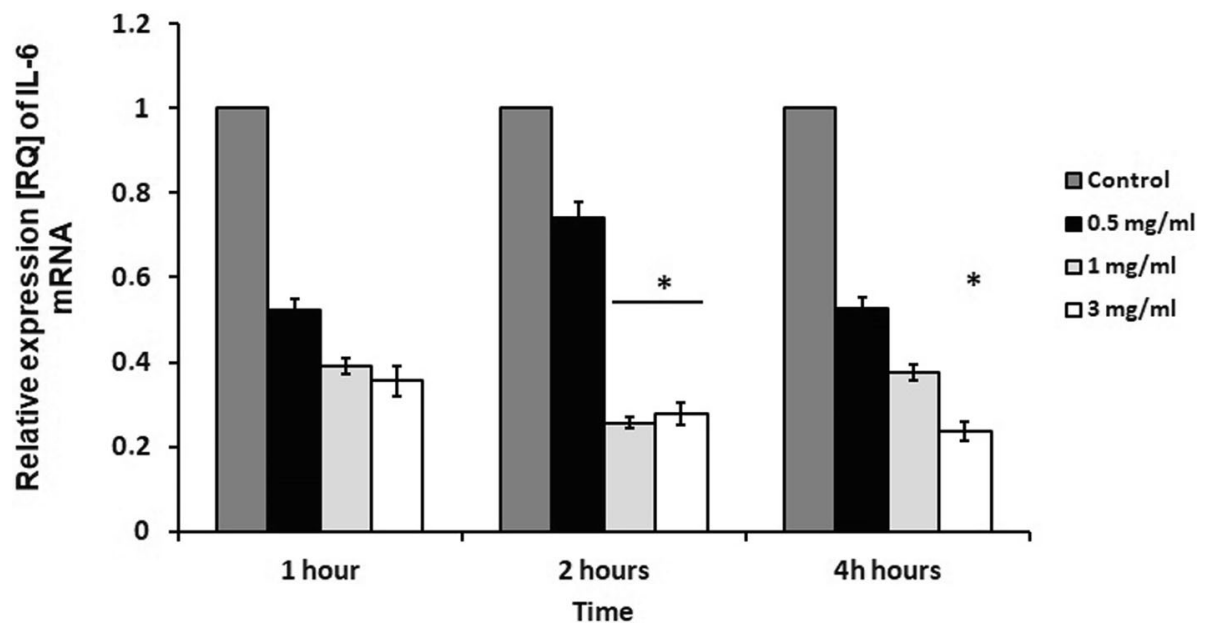

Fig. 1. mRNA expression levels of $I L-6$ in response to apocynin. Apocynin decreased IL-6 mRNA expression in A549 cells after 2 and $4 \mathrm{~h}$ of incubation at $1 \mathrm{mg} / \mathrm{ml}$ and $3 \mathrm{mg} / \mathrm{ml}$ concentrations $(p<0.05)$. Data presented as relative expression (RQ) $\pm \mathrm{SD},{ }^{*} p<0.05$.

concentration of apocynin significantly decreased TSLP expression after $2 \mathrm{~h}$ of application $(p<0.05)$, and no significant changes were observed after $4 \mathrm{~h}$ $(p>0.05)$; nevertheless, the trend was maintained (Fig. 5).

\section{Apocynin Upregulated PPAR- $\gamma$ mRNA Expression}

At each time point, apocynin increased the expression of PPAR- $\gamma$ in a dose-dependent manner; however, only after $2 \mathrm{~h}$ of apocynin application, this change was significant $(1 \mathrm{mg} / \mathrm{ml}$ and $3 \mathrm{mg} / \mathrm{ml}, p<0.05$, Fig. 6$)$.

\section{DISCUSSION}

As oxidative stress has previously been confirmed to play a role in the pathogenesis of many airway diseases [41-46], the present study evaluates the biological effect of the inhibition of NADPH oxidase by apocynin. To achieve this, qPCR was used to analyze the mRNA expression of selected genes, thus confirming their activity and the significance of apocynin in their potential regulation.

Our previous study on the effectiveness of inhaled apocynin on hydrogen peroxide, nitrate, and nitrite concentrations in humans found noticeable effects in healthy subjects, asthmatics, and COPD patients without any

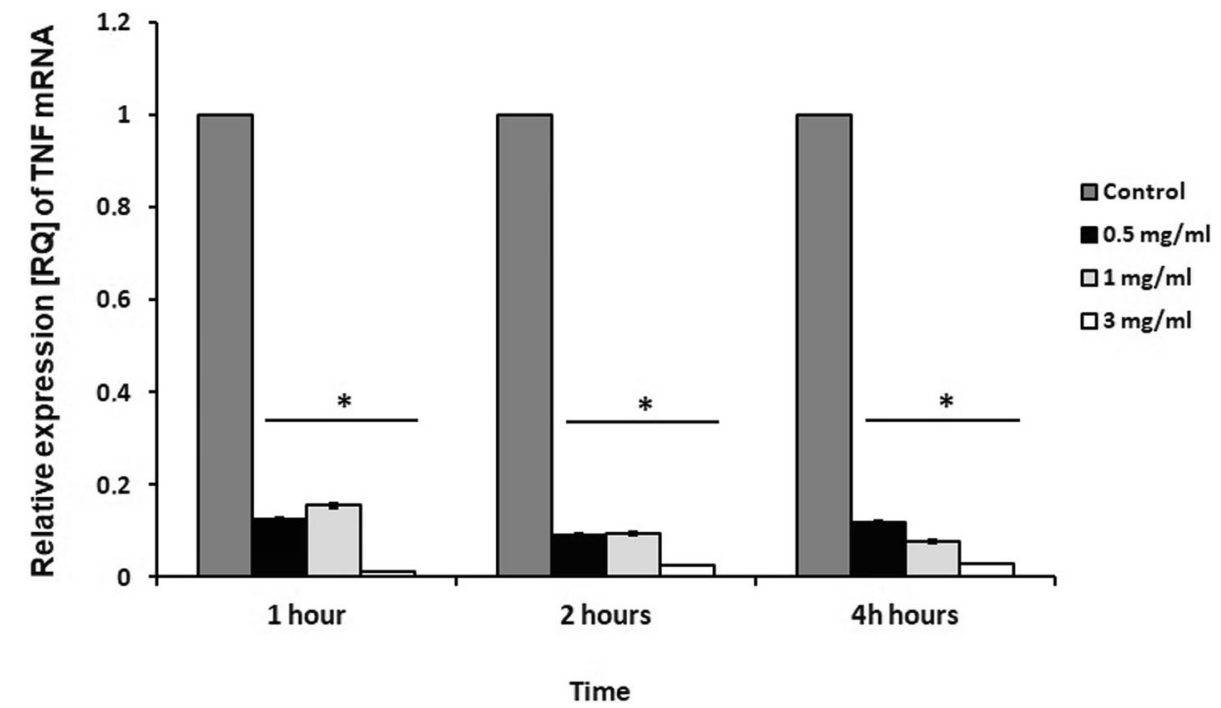

Fig. 2. The effect of apocynin on relative expression of TNF- $\alpha$ in A549 cells. A549 cells presented significantly decreased expression in response to apocynin after incubation at all concentrations and in all time points $(p<0.05)$. Data presented as relative expression $(\mathrm{RQ}) \pm \mathrm{SD}, * p<0.05$. 


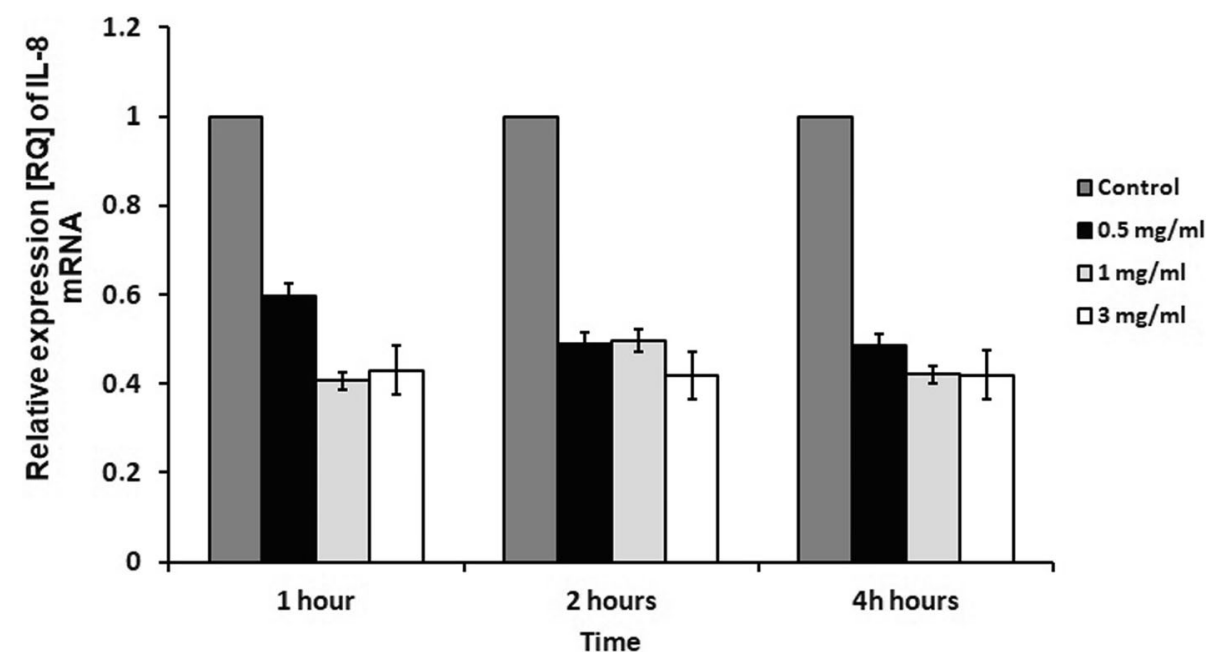

Fig. 3. Relative expression of IL- 8 after apocynin stimulation. No statistical significance in expression of IL-8 was observed after apocynin treatment $(p>0.05)$. Data presented as relative expression $(\mathrm{RQ}) \pm \mathrm{SD}$.

adverse effects [47-49]. In this study, unstimulated epithelial A549 cell was used. Our goal was to investigate the effect of the ROS restriction in such cells, as they might be regarded as more nearly reflecting the in vivo situation. ROS reduction by apocynin turned out to trigger the effect on the basal state of the cells. This might indicate further direction of the research to understand the mechanisms of this phenomenon and its consequences.

Although elevated IL- 6 has long been considered a general marker of inflammation, Naik et al. suggest that IL6 is not just a proinflammatory marker, but a key factor that contributes to the pathogenesis of some important inflammatory diseases, including asthma; it may hence serve as both a biomarker and a therapeutic target for asthma $[10$, 50]. Plasma levels of IL-6 are known to be increased in patients with stable COPD compared to controls [51], remain elevated for a period, and may contribute to the increased risk of depression and mortality associated with COPD [52-54].

The present study examined the expression of proinflammatory cytokines known to be associated with inflammatory airway diseases such as asthma and COPD (IL-6, IL-8, and TNF- $\alpha$ mRNA) after apocynin treatment. Apocynin appeared to lower the mRNA expression of each; however, only in the case of IL- 6 and TNF- $\alpha$ were the results significant. These data confirm those of Kim

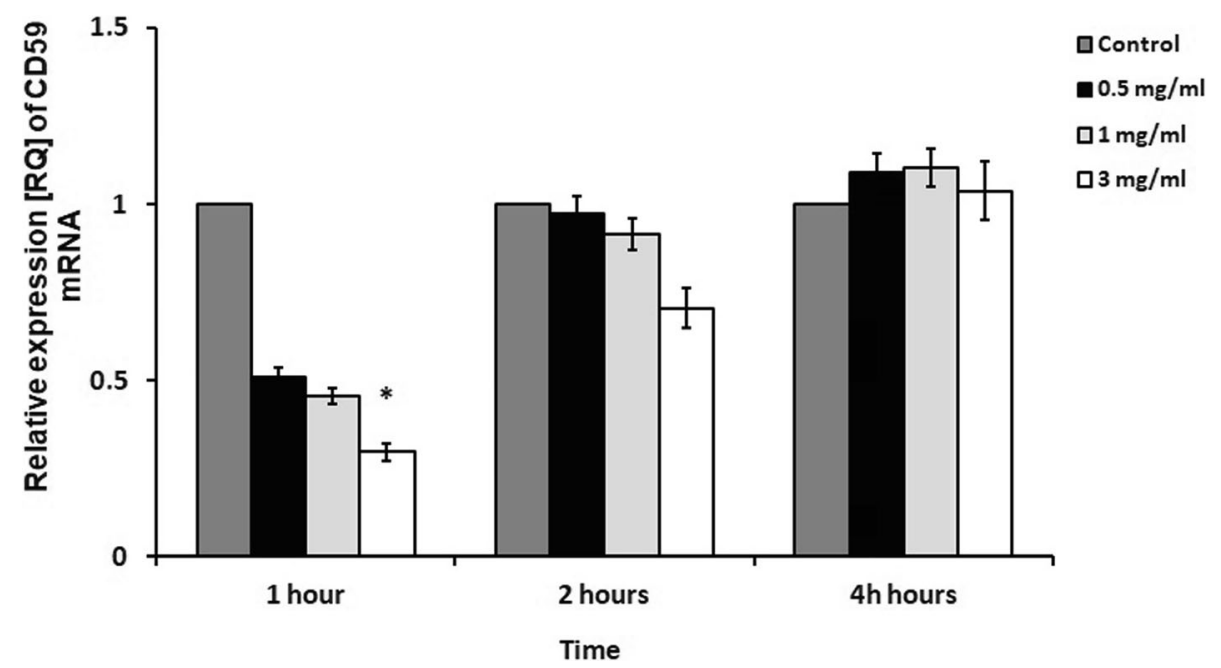

Fig. 4. CD-59 expression in PBMC of smokers and nonsmokers. Apocynin caused significant decrease of CD-59 mRNA expression after $1 \mathrm{~h}$ of application at $3 \mathrm{mg} / \mathrm{ml}$ concentration only $(p<0.05)$. Data presented as relative expression (RQ) $\pm \mathrm{SD},{ }^{*} p<0.05$. 


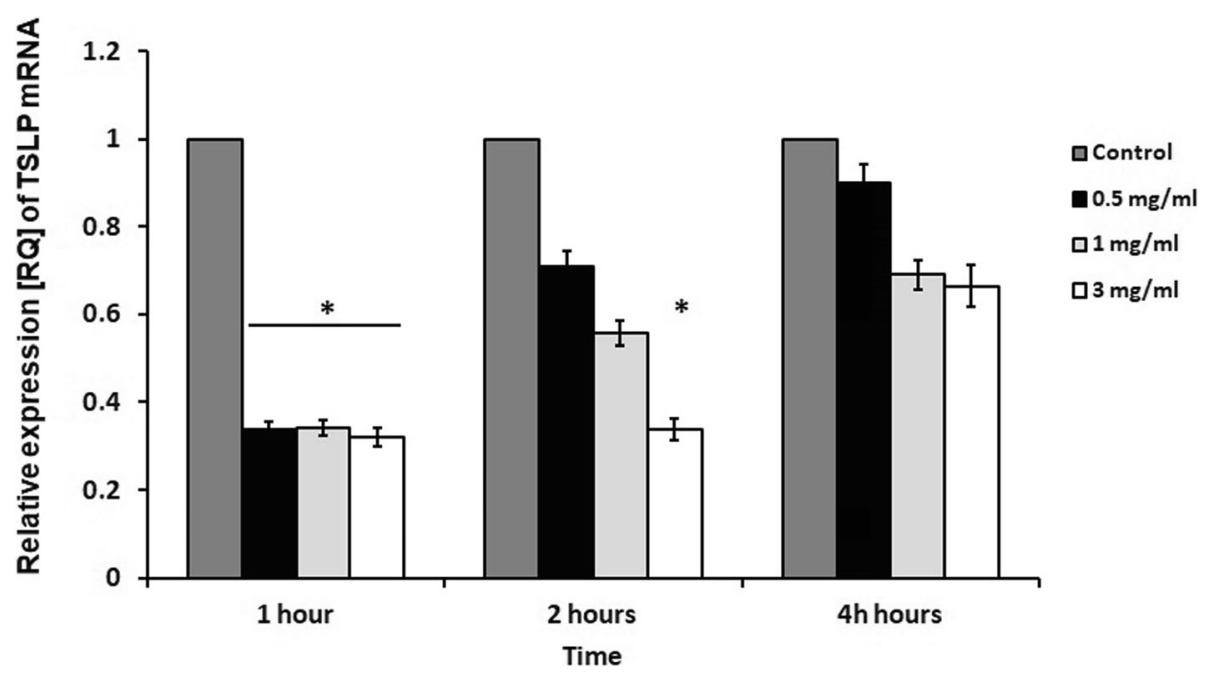

Fig. 5. mRNA expression levels of TSLP in response to apocynin. Apocynin decreased TSLP mRNA expression in A549 cells after $1 \mathrm{~h}$ of incubation at all concentrations used and after $2 \mathrm{~h}$ at the highest concentrations only $(p<0.05)$. Data presented as relative expression $(\mathrm{RQ}) \pm \mathrm{SD},{ }^{*} p<0.05$.

et al. [55] who found that TNF- $\alpha$ production was significantly attenuated after treatment with apocynin in a mouse model. They also demonstrated that treatment of OVAinduced asthma mice with apocynin effectively attenuated airway lung inflammation, Th2 cytokine production, and the infiltration of inflammatory cells, such as macrophages and eosinophils, into lung tissues [55].

Kilic et al. report that application of apocynin reversed elevated levels of IL-8 [56]. These findings confirm those of Perng et al. [57] and those of our present study. Moreover, Higai et al. indicate that apocynin, next to NAC, suppressed IL-8 mRNA expression induced by glycated human serum albumin [58], which also correlates with our research.

The inhibitory effect of apocynin on the production of proinflammatory cytokines was previously demonstrated in ventilator-induced lung injury models, where treatment with apocynin repaired the structural lung injury $[56,59]$. Interestingly, our findings indicate that another proiinflammatory cytokine, TSLP, was inhibited by all administered concentrations of apocynin after $1 \mathrm{~h}$ of application. In human bronchial epithelial cells, TSLP expression is associated with asthma severity [20, 60-62].

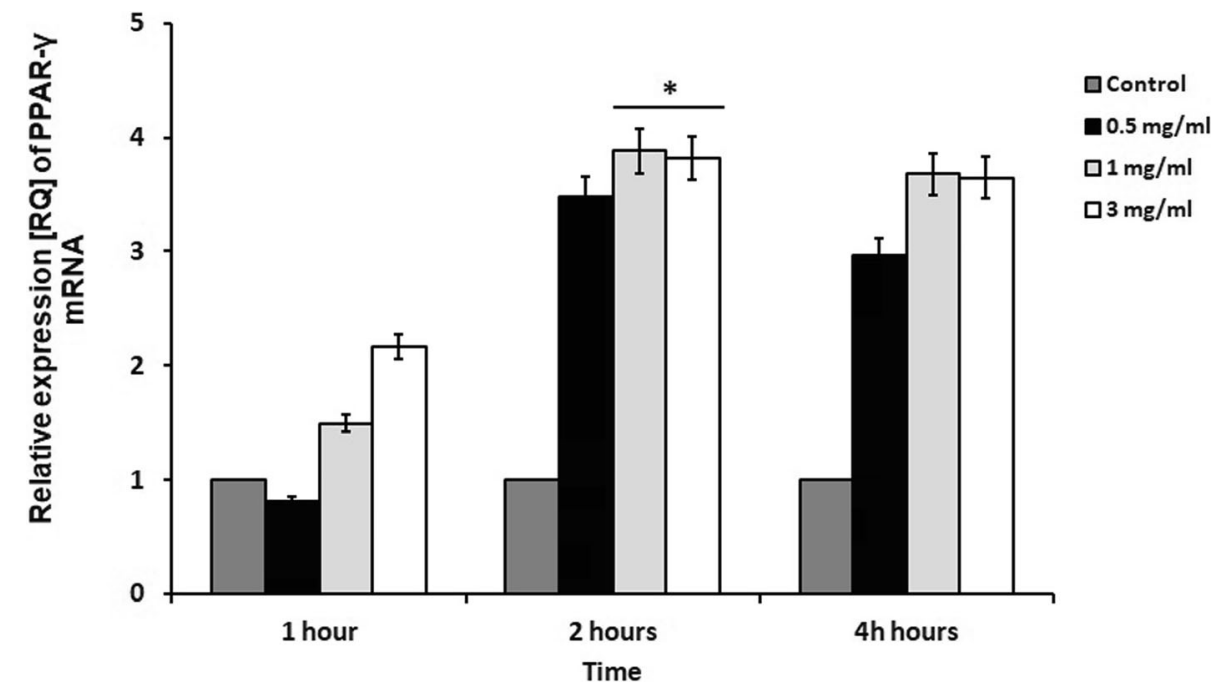

Fig. 6. The effect of apocynin on relative expression of PPAR- $\gamma$ in A549 cells. A549 cells showed an increase of PPAR- $\gamma$ relative expression after 4 h of incubation in the two highest concentrations of apocynin $(1 \mathrm{mg} / \mathrm{ml}$ and $3 \mathrm{mg} / \mathrm{ml}, p<0.05)$. Data presented as relative expression (RQ) $\pm \mathrm{SD},{ }^{*} p<0.05$. 
TSLP expression in the airway epithelium is inducible through an NF-KB-dependent pathway [54, 63, 64]. An increased number of cells expressing TSLP mRNA has been reported in the bronchi of stable COPD patients and smoking controls with normal lung function, and increased TSLP immunostaining has been shown in the smooth muscle of patients with stable COPD compared to nonsmoking subjects $[21,54,65]$. Furthermore, NF-kB, which regulates the release of many cytokines and chemokines, is shown to be responsive to oxidative stress $[20,66]$. It has been proposed recently [67] that the elevated TSLP production in the bronchial mucosa in COPD may be associated with the activation of NF- $\mathrm{KB}$ by oxidative stress from cigarette smoke [20, 64, 68].

The expression of TSLP mRNA in neutrophils and epithelial macrophages is also significantly higher in asthmatics than healthy controls. There is also a negative correlation between levels of lung function in asthmatics and TSLP expression $[21,69]$. Therefore, our results indicate oxidative stress influences TSLP level and may act as an inhibitor.

Huang et al. report that PPAR- $\gamma$ activation attenuates TNF- $\alpha$-enhanced ICAM-1 expression [70]. These data confirm our present results, which note that an increase of PPAR- $\gamma$ mRNA expression is accompanied by a decrease of TNF- $\alpha$ after apocynin treatment. Previous studies have suggested that PPAR $-\gamma$ activation alleviates asthmatic features, as evidenced by decreased expression of cytokines, reduced bronchoconstriction, and impaired eosinophil accumulation [71-73].

$\mathrm{Xu}$ et al. note that the administration of rosiglitazone, a PPAR- $\gamma$ agonist, attenuated asthmatic features including airway eosinophil accumulation, inflammatory cytokine levels, smooth muscle layer thickness, and collagen deposition in a mouse model. These findings suggest that the therapeutic effect against asthma exerted by rosiglitazone was associated with activation of PPAR- $\gamma$ and its downstream pathways [71].

In addition, Soletti et al. report that pharmacological PPAR- $\gamma$ activation protects from smoke-induced inflammation in vivo in mice, and attenuates the cellular and molecular intermediates of emphysema pathogenesis in humans. Pparg induction in epithelial cells appears to represent a protective mechanism against cigarette smoke-induced injury response, where it may function to suppress NF- $\mathrm{kB}$-mediated proinflammatory chemokine expression in an activationdependent fashion [74].

The current study indicates that inhibition of NADPH oxidase decreased CD59 mRNA expression after $1 \mathrm{~h}$. The functions of the CD59 protein are mainly involved in the MAC of human complement [75] signal stimulant, inducing the activation of $\mathrm{T}$ lymphocytes [76], and acting as a ligand of CD2. As bronchial epithelial cells express high levels of CD59 and that CD59 release is associated with cellular damage [28, 77], Budding et al. hypothesize that CD59 may be a marker for inflammatory lung tissue damage [26]. Therefore, the CD59-decreasing function of apocynin may shed new light on inflammation resolution and maintenance.

Apocynin appears to be a noteworthy molecule, with various promising features that can be employed in anti-oxidative and anti-inflammatory therapy; however, our study has some limitations. One such weakness is that it examines mRNA expression, but not protein expression. In addition, the A549 line used in the study are cancer cells: The main disadvantage of using cell lines is that the phenotype they express may not be consistent with the true phenotype of their primary counterparts [78]. Nevertheless, A549 cells constitute a useful in vitro model for studying human respiratory epithelial cell biology, as they exhibit characteristics similar to human alveolar type II cells [79].

We are aware that the weakness of the study is the lack of protein expression results and that mRNAs are not equal with regard to translation into proteins; thus, our results must be interpreted with caution. The mRNA expression alone analysis is incomplete, but shows that apocynin causes visible changes that can also be expressed at the protein level. This, however, indicates apocynin as a molecule worthy of interest.

With awareness of the effects of ROS on airway inflammation growing, antioxidant interventions have become a popular therapeutic target. Different research teams have reported that $\alpha$-tocopherol and vitamin $C$ combination therapy was effective in mitigating the effect of ozoneinduced lung function decrements in asthmatics [80-83], or in normal volunteers who had consumed an antioxidantdepleted diet for 3 weeks to mimic a state of poor antioxidant nutritional status $[81,83]$.

In conclusion, oxidative stress plays an important role in many diseases, especially in inflammatory diseases. Its strong and effective inhibition might help to reduce inflammation and local pathogenic changes. The results presented in the current study suggest that inhibition of NADPH oxidase might be a potential target in inflammatory diseases, and apocynin seems to be an interesting molecule in this regard; however, wider studies are needed to specifically explore this topic. 


\section{FUNDING INFORMATION}

This work was supported by the National Science Centre [2015/19/D/NZ6/02988] and Medical University of Lodz [503/0-148-03/503-01].

\section{COMPLIANCE WITH ETHICAL STANDARDS}

Conflict of Interest. The authors declare that they have no conflict of interest.

Open Access This article is distributed under the terms of the Creative Commons Attribution 4.0 International License (http://creativecommons.org/licenses/by/4.0/), which permits unrestricted use, distribution, and reproduction in any medium, provided you give appropriate credit to the original author(s) and the source, provide a link to the Creative Commons license, and indicate if changes were made.

\section{REFERENCES}

1. da Costa, A.F., J.A. Moraes, J.S. de Oliveira, M. dos Santos, S. Santos Gda, C. Barja-Fidalgo, A.L. Mattos-Guaraldi, and P.E. Nagao. 2016. Reactive oxygen species involved in apoptosis induction of human respiratory epithelial (A549) cells by Streptococcus agalactiae. Microbiology 162: 94-99.

2. Talbot, S., J.C. Lin, K. Lahjouji, et al. 2011. Cigarette smokeinduced kinin B1 receptor promotes NADPH oxidase activity in cultured human alveolar epithelial cells. Peptides 32: 1447-1456.

3. Stolk, J., T.J. Hiltermann, J.H. Dijkman, and A.J. Verhoeven. 1994. Characteristics of the inhibition of NADPH oxidase activation in neutrophils by apocynin, a methoxy-substituted catechol. American Journal of Respiratory Cell and Molecular Biology 11: 95-102.

4. Stolk, J., W. Rossie, and J.H. Dijkman. 1994. Apocynin improves the efficacy of secretory leukocyte protease inhibitor in experimental emphysema. American Journal of Respiratory and Critical Care Medicine 150: 1628-1631.

5. Tsai, M.H., J.F. Liu, Y.C. Chiang, et al. 2017. Artocarpin, an isoprenyl flavonoid, induces p53-dependent or independent apoptosis via ROS-mediated MAPKs and Akt activation in non-small cell lung cancer cells. Oncotarget 8: 28342-28358.

6. Lee, I.T., and C.M. Yang. 2012. Role of NADPH oxidase/ROS in pro-inflammatory mediators-induced airway and pulmonary diseases. Biochemical Pharmacology 84: 581-590.

7. Rahman, I., and W. MacNee. 2000. Oxidative stress and regulation of glutathione in lung inflammation. The European Respiratory Journal 16: 534-554.

8. Gorska, K., P. Nejman-Gryz, M. Paplinska-Goryca, P. Korczynski, M. Prochorec-Sobieszek, and R. Krenke. 2018. Comparative study of IL-33 and IL-6 levels in different respiratory samples in mild-tomoderate asthma and COPD. COPD 15: 36-45.
9. Gorska, K., P. Korczynski, M. Mierzejewski, J. Kosciuch, M. Zukowska, M. Maskey-Warzechowska, and R. Krenke. 2016. Comparison of endobronchial ultrasound and high resolution computed tomography as tools for airway wall imaging in asthma and chronic obstructive pulmonary disease. Respiratory Medicine 117: 131-138.

10. Naik, S. P., P, A. M., B, S. J., Madhunapantula, S. V., Jahromi, S. R., Yadav, M. K. 2017. Evaluation of inflammatory markers interleukin6 (IL-6) and matrix metalloproteinase-9 (MMP-9) in asthma. The Journal of Asthma 54:584-593.

11. Liu, C.W., T.L. Lee, Y.C. Chen, et al. 2018. PM2.5-induced oxidative stress increases intercellular adhesion molecule-1 expression in lung epithelial cells through the IL-6/AKT/STAT3/NF-kappaB-dependent pathway. Particle and Fibre Toxicology 15: 4.

12. Galun, E., E. Zeira, O. Pappo, M. Peters, and S. Rose-John. 2000. Liver regeneration induced by a designer human IL-6/sIL-6R fusion protein reverses severe hepatocellular injury. The FASEB Journal 14: 1979-1987.

13. Haga, S., K. Terui, H.Q. Zhang, S. Enosawa, W. Ogawa, H. Inoue, T. Okuyama, K. Takeda, S. Akira, T. Ogino, K. Irani, and M. Ozaki. 2003. Stat3 protects against Fas-induced liver injury by redoxdependent and -independent mechanisms. The Journal of Clinical Investigation 112: 989-998.

14. Viezeliene, D., P. Beekhof, E. Gremmer, H. Rodovicius, I. Sadauskiene, E. Jansen, and L. Ivanov. 2013. Selective induction of IL- 6 by aluminum-induced oxidative stress can be prevented by selenium. Journal of Trace Elements in Medicine and Biology 27: 226-229.

15. El-Assal, O., F. Hong, W.H. Kim, S. Radaeva, and B. Gao. 2004. IL6-deficient mice are susceptible to ethanol-induced hepatic steatosis: IL-6 protects against ethanol-induced oxidative stress and mitochondrial permeability transition in the liver. Cellular \& Molecular Immunology 1: 205-211.

16. Sacheck, J.M., J.G. Cannon, K. Hamada, E. Vannier, J.B. Blumberg, and R. Roubenoff. 2006. Age-related loss of associations between acute exercise-induced IL-6 and oxidative stress. American Journal of Physiology. Endocrinology and Metabolism 291: E340-E349.

17. Matera, M.G., L. Calzetta, and M. Cazzola. 2010. TNF-alpha inhibitors in asthma and COPD: we must not throw the baby out with the bath water. Pulmonary Pharmacology \& Therapeutics 23: 121-128.

18. Moodie, F.M., J.A. Marwick, C.S. Anderson, et al. 2004. Oxidative stress and cigarette smoke alter chromatin remodeling but differentially regulate NF-kappaB activation and proinflammatory cytokine release in alveolar epithelial cells. The FASEB Journal 18: 1897-1899.

19. Rahman, I. 2005. The role of oxidative stress in the pathogenesis of COPD: implications for therapy. Treatments in Respiratory Medicine 4: 175-200.

20. Redhu, N.S., and A.S. Gounni. 2012. Function and mechanisms of TSLP/TSLPR complex in asthma and COPD. Clinical and Experimental Allergy 42: 994-1005.

21. Ying, S., B. O'Connor, J. Ratoff, Q. Meng, C. Fang, D. Cousins, G. Zhang, S. Gu, Z. Gao, B. Shamji, M.J. Edwards, T.H. Lee, and C.J. Corrigan. 2008. Expression and cellular provenance of thymic stromal lymphopoietin and chemokines in patients with severe asthma and chronic obstructive pulmonary disease. Journal of Immunology 181: 2790-2798.

22. Nakamura, Y., M. Miyata, T. Ohba, T. Ando, K. Hatsushika, F. Suenaga, N. Shimokawa, Y. Ohnuma, R. Katoh, H. Ogawa, and A. Nakao. 2008. Cigarette smoke extract induces thymic stromal lymphopoietin expression, leading to $\mathrm{T}(\mathrm{H}) 2$-type immune responses and airway inflammation. The Journal of Allergy and Clinical Immunology 122: 1208-1214.

23. Pressey, A.W., and C.A. Pressey. 1992. Attentive fields are related to focal and contextual features: a study of Muller-Lyer distortions. Perception \& Psychophysics 51: 423-436. 
24. Blanquicett, C., B.Y. Kang, J.D. Ritzenthaler, D.P. Jones, and C.M. Hart. 2010. Oxidative stress modulates PPAR gamma in vascular endothelial cells. Free Radical Biology \& Medicine 48: 1618-1625.

25. Sommer, M., and G. Wolf. 2007. Rosiglitazone increases PPARgamma in renal tubular epithelial cells and protects against damage by hydrogen peroxide. American Journal of Nephrology 27: 425-434.

26. Budding, K., E.A. van de Graaf, T. Kardol-Hoefnagel, J.M. Kwakkelvan Erp, B.D. Luijk, E.J.D. Oudijk, D.A. van Kessel, J.C. Grutters, C.E. Hack, and H.G. Otten. 2016. Soluble CD59 is a novel biomarker for the prediction of obstructive chronic lung allograft dysfunction after lung transplantation. Scientific Reports 6: 26274.

27. Davies, A., D.L. Simmons, G. Hale, et al. 1989. CD59, an LY-6-like protein expressed in human lymphoid cells, regulates the action of the complement membrane attack complex on homologous cells. The Journal of Experimental Medicine 170: 637-654.

28. Meri, S., H. Waldmann, and P.J. Lachmann. 1991. Distribution of protectin (CD59), a complement membrane attack inhibitor, in normal human tissues. Laboratory Investigation 65: 532-537.

29. Li, B., H. Lin, J. Fan, et al. 2013. CD59 is overexpressed in human lung cancer and regulates apoptosis of human lung cancer cells. International Journal of Oncology 43: 850-858.

30. Barbieri, S.S., E. Zacchi, P. Amadio, S. Gianellini, L. Mussoni, B.B. Weksler, and E. Tremoli. 2011. Cytokines present in smokers' serum interact with smoke components to enhance endothelial dysfunction. Cardiovascular Research 90: 475-483.

31. Lee, I.T., S.F. Luo, C.W. Lee, S.W. Wang, C.C. Lin, C.C. Chang, Y.L. Chen, L.Y. Chau, and C.M. Yang. 2009. Overexpression of HO-1 protects against TNF-alpha-mediated airway inflammation by down-regulation of TNFR1-dependent oxidative stress. The American Journal of Pathology 175: 519-532.

32. Lee, C.W., C.C. Lin, I.T. Lee, H.C. Lee, and C.M. Yang. 2011. Activation and induction of cytosolic phospholipase A2 by TNF-alpha mediated through Nox2, MAPKs, NF-kappaB, and p300 in human tracheal smooth muscle cells. Journal of Cellular Physiology 226: 2103-2114.

33. Lin, C.P., P.H. Huang, H.S. Tsai, T.C. Wu, H.B. Leu, P.L. Liu, and Y.H. Chen. 2011. Monascus purpureus-fermented rice inhibits tumor necrosis factor-alpha-induced upregulation of matrix metalloproteinase 2 and 9 in human aortic smooth muscle cells. The Journal of Pharmacy and Pharmacology 63: 1587-1594.

34. Luo, S.F., C.C. Chang, I.T. Lee, C.W. Lee, W.N. Lin, C.C. Lin, and C.M. Yang. 2009. Activation of ROS/NF-kappaB and $\mathrm{Ca} 2+/ \mathrm{CaM}$ kinase II are necessary for VCAM-1 induction in IL-1beta-treated human tracheal smooth muscle cells. Toxicology and Applied Pharmacology 237: 8-21.

35. Pniewska, E., M. Sokolowska, I. Kuprys-Lipinska, M. Przybek, P. Kuna, and R. Pawliczak. 2014. The step further to understand the role of cytosolic phospholipase A2 alpha and group X secretory phospholipase A2 in allergic inflammation: Pilot study. BioMed Research International 2014: 670814.

36. Tsai, Y.S., Y.T. Tseng, P.S. Chen, M.C. Lin, C.C. Wu, M.S. Huang, C.C. Wang, K.S. Chen, Y.C. Lin, and T.N. Wang. 2016. Protective effects of elafin against adult asthma. Allergy and Asthma Proceedings 37: 15-24.

37. Wu, S., M. Wu, M. Qi, L. Zhong, and L. Qiu. 2018. Effects of novel brominated flame retardant TBBPA on human airway epithelial cell (A549) in vitro and proteome profiling. Environmental Toxicology 33: $1245-1253$

38. Lee, I.S., D.H. Cho, K.S. Kim, K.H. Kim, J. Park, Y. Kim, J.H. Jung, K. Kim, H.J. Jung, and H.J. Jang. 2018. Anti-inflammatory effects of embelin in A549 cells and human asthmatic airway epithelial tissues. Immunopharmacology and Immunotoxicology 40: 83-90.

39. Hsu, H.T., Y.T. Tseng, W.J. Wong, C.M. Liu, and Y.C. Lo. 2018. Resveratrol prevents nanoparticles-induced inflammation and oxidative stress via downregulation of PKC-alpha and NADPH oxidase in lung epithelial A549 cells. BMC Complementary and Alternative Medicine 18: 211.

40. Hussain, S., L.C. Thomassen, I. Ferecatu, M.C. Borot, K. Andreau, J.A. Martens, J. Fleury, A. Baeza-Squiban, F. Marano, and S. Boland. 2010. Carbon black and titanium dioxide nanoparticles elicit distinct apoptotic pathways in bronchial epithelial cells. Particle and Fibre Toxicology 7: 10.

41. Andrianjafimasy, M., F. Zerimech, Z. Akiki, H. Huyvaert, N. le Moual, V. Siroux, R. Matran, O. Dumas, and R. Nadif. 2017. Oxidative stress biomarkers and asthma characteristics in adults of the EGEA study. The European Respiratory Journal 50: 1701193.

42. McGuinness, A.J., and E. Sapey. 2017. Oxidative stress in COPD: sources, markers, and potential mechanisms. Journal of Clinical Medicine 6.

43. Mishra, V., J. Banga, and P. Silveyra. 2018. Oxidative stress and cellular pathways of asthma and inflammation: therapeutic strategies and pharmacological targets. Pharmacology \& Therapeutics 181: 169-182.

44. Choudhury, G., and W. MacNee. 2017. Role of inflammation and oxidative stress in the pathology of ageing in COPD: potential therapeutic interventions. COPD 14: 122-135.

45. Antus, B., and Z. Kardos. 2015. Oxidative stress in COPD: molecular background and clinical monitoring. Current Medicinal Chemistry 22: 627-650.

46. Bishopp, A., R. Sathyamurthy, S. Manney, C. Webbster, M.T. Krishna, and A.H. Mansur. 2017. Biomarkers of oxidative stress and antioxidants in severe asthma: a prospective case-control study. Annals of Allergy, Asthma \& Immunology 118: 445-451.

47. Stefanska, J., A. Sarniak, A. Wlodarczyk, M. Sokolowska, E. Pniewska, Z. Doniec, D. Nowak, and R. Pawliczak. 2012. Apocynin reduces reactive oxygen species concentrations in exhaled breath condensate in asthmatics. Experimental Lung Research 38: 90-99.

48. Stefanska, J., M. Sokolowska, A. Sarniak, A. Wlodarczyk, Z. Doniec, D. Nowak, and R. Pawliczak. 2010. Apocynin decreases hydrogen peroxide and nitrate concentrations in exhaled breath in healthy subjects. Pulmonary Pharmacology \& Therapeutics 23: 48-54.

49. Stefanska, J., A. Sarniak, A. Wlodarczyk, M. Sokolowska, Z. Doniec, P. Bialasiewicz, D. Nowak, and R. Pawliczak. 2012. Hydrogen peroxide and nitrite reduction in exhaled breath condensate of COPD patients. Pulmonary Pharmacology \& Therapeutics 25: 343-348.

50. Rincon, M., and C.G. Irvin. 2012. Role of IL-6 in asthma and other inflammatory pulmonary diseases. International Journal of Biological Sciences 8: 1281-1290.

51. Gan, W.Q., S.F. Man, A. Senthilselvan, and D.D. Sin. 2004. Association between chronic obstructive pulmonary disease and systemic inflammation: a systematic review and a meta-analysis. Thorax 59: 574-580.

52. Celli, B.R., N. Locantore, J. Yates, R. Tal-Singer, B.E. Miller, P. Bakke, P. Calverley, H. Coxson, C. Crim, L.D. Edwards, D.A. Lomas, A. Duvoix, W. MacNee, S. Rennard, E. Silverman, J. Vestbo, E. Wouters, A. Agustí, and for the ECLIPSE Investigators. 2012. Inflammatory biomarkers improve clinical prediction of mortality in chronic obstructive pulmonary disease. American Journal of Respiratory and Critical Care Medicine 185: 1065-1072.

53. Kelly, E., C.A. Owen, V. Pinto-Plata, and B.R. Celli. 2013. The role of systemic inflammatory biomarkers to predict mortality in chronic obstructive pulmonary disease. Expert Review of Respiratory Medicine 7: 57-64.

54. Caramori, G., I.M. Adcock, A. Di Stefano, and K.F. Chung. 2014. Cytokine inhibition in the treatment of COPD. International Journal of Chronic Obstructive Pulmonary Disease 9: 397-412.

55. Kim, S.Y., K.A. Moon, H.Y. Jo, S. Jeong, S.H. Seon, E. Jung, Y.S. Cho, E. Chun, and K.Y. Lee. 2012. Anti-inflammatory effects of 
apocynin, an inhibitor of NADPH oxidase, in airway inflammation. Immunology and Cell Biology 90: 441-448.

56. Kilic, T., H. Parlakpinar, E. Taslidere, S. Yildiz, A. Polat, N. Vardi, C. Colak, and H. Ermis. 2015. Protective and therapeutic effect of apocynin on bleomycin-induced lung fibrosis in rats. Inflammation 38: 1166-1180.

57. Perng, D.W., T.M. Chang, J.Y. Wang, C.C. Lee, S.H. Lu, S.K. Shyue, T.S. Lee, and Y.R. Kou. 2013. Inflammatory role of AMPactivated protein kinase signaling in an experimental model of toxic smoke inhalation injury. Critical Care Medicine 41: 120-132.

58. Higai, K., R. Sano, M. Satake, Y. Azuma, and K. Matsumoto. 2007. Glycated human serum albumin induces interleukin $8 \mathrm{mRNA}$ expression through reactive oxygen species and NADPH oxidasedependent pathway in monocyte-derived U937 cells. Biological \& Pharmaceutical Bulletin 30: 1833-1837.

59. Chiang, C.H., C.H. Chuang, S.L. Liu, T.S. Lee, Y.R. Kou, and H. Zhang. 2011. Apocynin attenuates ventilator-induced lung injury in an isolated and perfused rat lung model. Intensive Care Medicine 37: 1360-1367.

60. Bleck, B., D.B. Tse, T. Gordon, M.R. Ahsan, and J. Reibman. 2010. Diesel exhaust particle-treated human bronchial epithelial cells upregulate Jagged-1 and OX40 ligand in myeloid dendritic cells via thymic stromal lymphopoietin. Journal of Immunology 185: 6636-6645.

61. Liu, Y.J. 2006. Thymic stromal lymphopoietin: master switch for allergic inflammation. The Journal of Experimental Medicine 203: 269-273.

62. Ying, S., B. O'Connor, J. Ratoff, et al. 2005. Thymic stromal lymphopoietin expression is increased in asthmatic airways and correlates with expression of Th2-attracting chemokines and disease severity. Journal of Immunology 174: 8183-8190.

63. Allakhverdi, Z., M.R. Comeau, H.K. Jessup, B.R.P. Yoon, A. Brewer, S. Chartier, N. Paquette, S.F. Ziegler, M. Sarfati, and G. Delespesse. 2007. Thymic stromal lymphopoietin is released by human epithelial cells in response to microbes, trauma, or inflammation and potently activates mast cells. The Journal of Experimental Medicine 204: 253-258.

64. Lee, H.C., and S.F. Ziegler. 2007. Inducible expression of the proallergic cytokine thymic stromal lymphopoietin in airway epithelial cells is controlled by NFkappaB. Proceedings of the National Academy of Sciences of the United States of America 104: 914-919.

65. Zhang, K., L. Shan, M.S. Rahman, H. Unruh, A.J. Halayko, and A.S. Gounni. 2007. Constitutive and inducible thymic stromal lymphopoietin expression in human airway smooth muscle cells: role in chronic obstructive pulmonary disease. American Journal of Physiology. Lung Cellular and Molecular Physiology 293: L375-L382.

66. Rahman, I. 2000. Regulation of nuclear factor-kappa B, activator protein-1, and glutathione levels by tumor necrosis factor-alpha and dexamethasone in alveolar epithelial cells. Biochemical Pharmacology 60: 1041-1049.

67. Fang, C., L.Q. Siew, C.J. Corrigan, and S. Ying. 2010. The role of thymic stromal lymphopoietin in allergic inflammation and chronic obstructive pulmonary disease. Archivum Immunologiae et Therapiae Experimentalis (Warsz) 58: 81-90.

68. Kato, A., S. Favoreto Jr., P.C. Avila, and R.P. Schleimer. 2007. TLR3- and Th2 cytokine-dependent production of thymic stromal lymphopoietin in human airway epithelial cells. Journal of Immunology 179: 1080-1087.

69. Mitchell, P.D., and P.M. O'Byrne. 2017. Biologics and the lung: TSLP and other epithelial cell-derived cytokines in asthma. Pharmacology \& Therapeutics 169: 104-112.
70. Huang, C.D., T.C. Hsiung, S.C. Ho, et al. 2014. PPARgamma ligand ciglitazone inhibits TNFalpha-induced ICAM-1 in human airway smooth muscle cells. Biomedical Journal 37: 191-198.

71. Xu, J., Y.T. Zhu, G.Z. Wang, D. Han, Y.Y. Wu, D.X. Zhang, Y. Liu, Y.H. Zhang, X.M. Xie, S.J. Li, J.M. Lu, L. Liu, W. Feng, X.Z. Sun, and M.X. Li. 2015. The PPARgamma agonist, rosiglitazone, attenuates airway inflammation and remodeling via heme oxygenase-1 in murine model of asthma. Acta Pharmacologica Sinica 36: 171-178.

72. Woerly, G., K. Honda, M. Loyens, J.P. Papin, J. Auwerx, B. Staels, M. Capron, and D. Dombrowicz. 2003. Peroxisome proliferatoractivated receptors alpha and gamma down-regulate allergic inflammation and eosinophil activation. The Journal of Experimental Medicine 198: 411-421.

73. Honda, K., P. Marquillies, M. Capron, and D. Dombrowicz. 2004. Peroxisome proliferator-activated receptor gamma is expressed in airways and inhibits features of airway remodeling in a mouse asthma model. The Journal of Allergy and Clinical Immunology 113: 882-888.

74. Solleti, S.K., D.M. Simon, S. Srisuma, M.C. Arikan, S. Bhattacharya, T. Rangasamy, K.M. Bijli, A. Rahman, J.T. Crossno Jr., S.D. Shapiro, and T.J. Mariani. 2015. Airway epithelial cell PPARgamma modulates cigarette smoke-induced chemokine expression and emphysema susceptibility in mice. American Journal of Physiology. Lung Cellular and Molecular Physiology 309: L293-L304.

75. Sugita, Y., Y. Nakano, E. Oda, K. Noda, T. Tobe, N.H. Miura, and M. Tomita. 1993. Determination of carboxyl-terminal residue and disulfide bonds of MACIF (CD59), a glycosyl-phosphatidylinositolanchored membrane protein. Journal of Biochemistry 114: 473-477.

76. Treon, S.P., Y. Shima, M.L. Grossbard, F.I. Preffer, A.R. Belch, L.M. Pilarski, and K.C. Anderson. 2000. Treatment of multiple myeloma by antibody mediated immunotherapy and induction of myeloma selective antigens. Annals of Oncology 11 (Suppl 1): 107-111.

77. Vakeva, A., T. Lehto, A. Takala, and S. Meri. 2000. Detection of a soluble form of the complement membrane attack complex inhibitor CD59 in plasma after acute myocardial infarction. Scandinavian Journal of Immunology 52: 411-414.

78. Clover, J., and M. Gowen. 1994. Are MG-63 and HOS TE85 human osteosarcoma cell lines representative models of the osteoblastic phenotype? Bone 15: 585-591.

79. Li, N., M. Hao, R.F. Phalen, W.C. Hinds, and A.E. Nel. 2003. Particulate air pollutants and asthma. A paradigm for the role of oxidative stress in PM-induced adverse health effects. Clinical Immunology 109: 250-265.

80. Romieu, I., J.J. Sienra-Monge, M. Ramirez-Aguilar, et al. 2002. Antioxidant supplementation and lung functions among children with asthma exposed to high levels of air pollutants. American Journal of Respiratory and Critical Care Medicine 166: 703-709.

81. Samet, J.M., G.E. Hatch, D. Horstman, et al. 2001. Effect of antioxidant supplementation on ozone-induced lung injury in human subjects. American Journal of Respiratory and Critical Care Medicine 164: 819-825.

82. Trenga, C.A., J.Q. Koenig, and P.V. Williams. 2001. Dietary antioxidants and ozone-induced bronchial hyperresponsiveness in adults with asthma. Archives of Environmental Health 56: 242-249.

83. Auerbach, A., and M.L. Hernandez. 2012. The effect of environmental oxidative stress on airway inflammation. Current Opinion in Allergy and Clinical Immunology 12: 133-139.

Publisher's Note Springer Nature remains neutral with regard to jurisdictional claims in published maps and institutional affiliations. 